\title{
Copper scavenging efficiency of adsorbents prepared from Raphia hookeri fruit waste
}

\author{
Adejumoke Abosede Inyinbor $^{\mathrm{a}, *}$, Folahan Amoo Adekola ${ }^{\mathrm{b}}$, Gabriel Ademola Olatunji ${ }^{\mathrm{b}}$

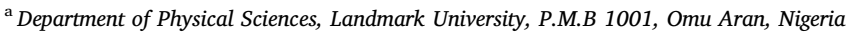 \\ ${ }^{\mathrm{b}}$ Department of Industrial Chemistry, University of Ilorin, P.M.B 1515, Ilorin, Nigeria
}

\section{A R T I C L E I N F O}

\section{Keywords:}

Low cost adsorbent

Copper

Adsorption

Kinetics

Isotherms

\begin{abstract}
A B S T R A C T
Low cost adsorbents prepared from the epicarp of Raphia hookeri fruit were used for the removal of copper (II) ion from aqueous solution. The effects of operational parameters such as $\mathrm{pH}$, concentration and contact time, dosage as well as interference of other ions were studied. Optimum $\mathrm{pH}$ for raw and modified biomass were 5.0 and 5.5 with percentage removal of $75.08 \%$ and $95.62 \%$ respectively. Concentration of competing ions greatly reduced $\mathrm{Cu}^{2+}$ removal with both adsorbents while agitation speed had negligible effect on $\mathrm{Cu}^{2+}$ uptake. Adsorbents surfaces were activated as temperature increased thus enhancing adsorbent adsorption capacity at high temperature. Adsorption kinetic data fitted best into the pseudo second order model while the thermodynamics studies confirmed adsorption spontaneity and feasibility. The Freundlich adsorption isotherm best described the adsorption process and the Langmuir maximum monolayer adsorption capacity for the raw (RHE) and acid treated (ARHE) biomass were 81.97 and $103.09 \mathrm{mg} / \mathrm{g}$ respectively. Chemisorption predominate the $\mathrm{Cu}^{2+}$-ARHE system hence desorption efficiency was obtained to be $72.65 \%$ with $\mathrm{CH}_{3} \mathrm{COOH}$ as eluent.
\end{abstract}

\section{Introduction}

Wastewater from industries come with high loads of organic pollutants such as dyes, phenols, herbicides, pesticides, pharmaceutical and personal care products amongst others as well as inorganic pollutant of which metals of toxicological concerns takes the lead (Li et al., 2018). The discharge of these result in serious water pollution and deterioration. The non-biodegradable nature of metals of toxicological concerns results in their bioaccumulation both in the environment and humans hence, causes serious health challenges (Meng et al., 2018; Siyal et al., 2018). For instance, copper which is regularly released from various industrial activities including smelting, fertilizer, electroplating, mining and other metal finishing industries, petrochemical and electrical cable productions could have various health effects on human. Human exposure to excess copper may result in upper abdominal pain, diarrhea, nausea, vomiting, hepatic and renal dysfunction, various types of cancer and even death (Liu et al., 2019).

The maximum allowable limit for copper in drinking water has been set to $2 \mathrm{mg} / \mathrm{L}$ (WHO, 2003). Various reports of copper and other metals of toxicological concerns in drinking water has been traced to leaching from water conducting pipes amongst other sources (Harvey et al., 2016; Nthunya et al., 2017). However, rural dwellers who have no access to tap water largely depends on river water for drinking and other uses. These river bodies may have been polluted with various industrial discharge containing the afore mentioned metals and other pollutants (Genthe et al., 2018; Titilawo et al., 2018; Xiao et al., 2019). Therefore effective wastewater treatment before their discharge will promote sustainability as well as protect humans.

Adsorption technique has been singled out as an effectively efficient method of wastewater treatment (Adekola et al., 2019). The expensive activated carbon being used in adsorption technique however limits its access hence the need for alternative economical adsorbent. In our previous work, we utilized raw and acid treated Raphia hookeri fruits epicarp for the adsorption of rhodamine B dye (Inyinbor et al., 2016 and 2016a). Prepared adsorbents were found unique and highly effective. To the best of our knowledge, until now, there is no reports regarding the use of raw and treated $R$. hookeri in the removal of metals of toxicological concerns.

Our focus here is to emphasize the efficacy of economic and sustainable adsorbents in the removal of a toxic metal (copper). Effects of various operational parameters as well as equilibrium, kinetics and thermodynamic analysis which substantiate their applications in industries are herein reported. Possibility of their reuse were also investigated and reported.

\footnotetext{
* Corresponding author.

E-mail address: inyinbor.adejumoke@landmarkuniversity.edu.ng (A.A. Inyinbor).
} 


\section{Materials and methods}

\subsection{Biomass collection and preparation}

Fruits of $R$. hookeri palm were collected from native farmers of Mokogi community, Bacita in Edu local government area of kwara state, Nigeria latitude $\left(9^{\circ} 4^{\prime} 59.99^{\prime \prime} \mathrm{N}\right.$ and longitude $\left.4^{\circ} 57^{\prime} 0.00^{\prime \prime} \mathrm{E}\right)$. The fruits were neatly dehulled, the epicarps (RHE) were washed with water, sun dried and transported to the laboratory. RHE were washed again with deionized water and subsequently dried in a low temperature oven over the night. RHE was smoothly grounded and further screened into a particle size range of 150-250 $\mu \mathrm{m}$. RHE was stored in air tight container for subsequent usage. Acid treatment of RHE was previously reported (Inyinbor et al., 2015). Acid treated RHE (ARHE) was also kept in an air tight container for subsequent usage.

\subsection{Preparation of stock solution of $\mathrm{Cu}^{2+}$}

A stock solution of $1000 \mathrm{mg} / \mathrm{L} \mathrm{Cu}$ (II) was prepared by dilution of $3.931 \mathrm{~g} \mathrm{CuSO}_{4} .5 \mathrm{H}_{2} \mathrm{O}$ (Analytical grade supplied by Lobal Chemie, India) in $1 \mathrm{dm}^{3}$ deionized water. Subsequent working solutions of 20 , $40,60,80$ and $100 \mathrm{mg} / \mathrm{L}$ were prepared by serial dilution of the stock solution.

\subsection{Adsorbent characterization}

Methods employed in surface chemistry, surface morphology physicochemical parameters determination as well as characterization details were presented in our previous studies (Inyinbor et al., 2016 \& 2016a).

\subsection{Adsorption studies}

Adsorption process is greatly influenced by various operational parameters viz initial adsorbate concentration, adsorbent load, $\mathrm{pH}$, contact time, temperature, presence of competing ions and agitation speed. In this study, various operational parameters investigated were varied as follows; $\mathrm{pH}(2-5.5)$, dosage (1-5 g/L), agitation speed $(150-300 \mathrm{rpm})$, contact time $(120 \mathrm{~min})$ and temperature $\left(40-80^{\circ} \mathrm{C}\right)$. Varying concentration of $\mathrm{NaCl}(0.1,0.01$ and $0.001 \mathrm{M})$ was used to establish the effect of competing ion on adsorption of $\mathrm{Cu}^{2+}$. In general, $100 \mathrm{~cm}^{3}$ of adsorbate solution was added to a fixed mass of the adsorbent in plastic bottles, the bottles were properly sealed and agitated on a temperature controlled water bath shaker operating at a fixed temperature and specified speed until equilibrium. Details of conditions for each study is presented with their figures. Spent adsorbent was separated out by filtration and the residual metal ion concentration were obtained using an atomic absorption spectrophotometer (AAS, Aanalyte 400 with detection limit of $0.008 \mu \mathrm{g} / \mathrm{ml}$ and calibrated with series of standard solution of $\mathrm{Cu}^{2+}$ ). Quantity adsorbed and percentage adsorbed were obtained using the mathematical relations 1 and 2 .

$q_{t}=\frac{\left(C_{i}-C_{t}\right)}{M} \times V$

$\%$ Removal $=\frac{\left(\boldsymbol{C}_{i}-\boldsymbol{C}_{\boldsymbol{t}}\right)}{\boldsymbol{C}_{\boldsymbol{t}}} \times 100$

Initial metal ion concentration is $\mathrm{C}_{\mathrm{i}}, \mathrm{C}_{\mathrm{t}}$ is metal ion concentration at time $t$ and $C_{f}$ is the final metal ion concentration. $V$ is the volume of aqueous copper (II) used for the adsorption studies in liter and $\mathrm{M}$ is the weight of the adsorbent in $\mathrm{g}$.

\subsection{Desorption experiment}

Neutral water, $0.1 \mathrm{M} \mathrm{HCl}$ and $0.1 \mathrm{M} \mathrm{CH}_{3} \mathrm{COOH}$ were eluents used for the desorption studies. Loaded adsorbent $(0.1 \mathrm{~g})$ was added to $100 \mathrm{~cm}^{3}$ of each eluent, the mixture was agitated in a temperature controlled water bath shaker set at $26^{\circ} \mathrm{C}$ temperature, $150 \mathrm{rpm}$ speed for $120 \mathrm{~min}$. The desorbed metal ion was consequently determined using AAS, analyte 400 and desorption efficiency was subsequently calculated following equation (3);

Desorption efficiency $(\%)=\frac{\boldsymbol{q}_{d e}}{\boldsymbol{q}_{a d}} \times 100$

\subsection{Mathematical modeling of adsorption data}

\subsubsection{Isothermal studies}

Analysis of equilibrium adsorption data using various isothermal models such as the Langmuir, (1916), Freundlich (1906), Temkin (Temkin and Pyzhev, 1940) and Dubinin-Radushkevich (D-R) (Dubinin and Radushkevich, 1947) helps to better understand modes and mechanism of adsorbate uptake onto the adsorbent. Equations (4) and (4a) are the Langmuir linear equation and the dimensionless factor $R_{L}$ respectively. Equations (5)-(7) are the linear equations of Freundlich, Temkin and D-R models respectively while the Polanyi potential $(\mathcal{E})$ and the mean energy of adsorption (E) are expressed by equations (7a) and (7b).

$\frac{C_{e}}{q_{e}}=\frac{C_{e}}{q_{\max }}+\frac{1}{q_{\max } K_{L}}$

$\mathrm{R}_{\mathrm{L}}=\frac{1}{\left(1+K_{L} C_{o}\right)}$

$\log \mathrm{q}_{\mathrm{e}}=\frac{1}{n} \log \mathrm{C}_{\mathrm{e}}+\log \mathrm{k}_{\mathrm{f}}$

$\mathrm{q}_{\mathrm{e}}=\mathrm{B} \ln \mathrm{A}+\mathrm{B} \ln \mathrm{C}_{\mathrm{e}}$

$\ln q_{e}=\ln q_{o}-\beta \varepsilon^{2}$

$\varepsilon=\mathrm{RT} \ln \left(1+\frac{1}{\mathrm{Ce}}\right)$

$\mathrm{E}=\sqrt{1} / 2 \beta$

$C_{\mathrm{e}}$ is the obtained concentration at equilibrium in $\mathrm{mg} / \mathrm{L}, q_{\mathrm{e}}$ is the ammount of $\mathrm{Cu}^{2+}$ taken onto the adsorbent surface at equilibrium $(\mathrm{mg} / \mathrm{g})$, $q_{\text {max }}$ is the Langmuir maximum monolayer adsorption capacity of adsorbent expressed in $\mathrm{mg} / \mathrm{g}$ and $\mathrm{K}_{\mathrm{L}}$ is the Langmuir adsorption constant calculated in $\mathrm{L} / \mathrm{mg}$. $\mathrm{K}_{\mathrm{f}}$ and $\mathrm{n}$ are Freundlich constants which incooperartes the factors affecting the adsorption capacity and adsorption intensity respectively. A is the Temkin isotherm constant $(\mathrm{L} / \mathrm{g})$, from the value of Temkin constant $\mathrm{B}$, a constant $\mathrm{b}(\mathrm{J} / \mathrm{mol})$ related to the heat of absorption can be obtained via the relation $\mathrm{B}=\mathrm{RT} / \mathrm{b}, \mathrm{T}$ is the temperature $(\mathrm{K}), \mathrm{R}$ is the gas constant $(8.314 \mathrm{~J} / \mathrm{mol} \mathrm{K}) . \beta$ which is the activity coefficient.

\subsubsection{Kinetics model}

Kinetics data were tested using the pseudo-first-order [Lagergren and Svenka, 1898], pseudo-second-order [Ho and McKay, 1999], Elovich [Aharoni and Ungarish, 1976], Avrami [Avrami, 1940], fractional power and Intraparticle diffusion [Weber and Morris, 1963] kinetic models. Their respective linear equations is as presented with equations (8)-(13).

$$
\begin{aligned}
& \ln \left(\mathrm{q}_{\mathrm{e}}-\mathrm{q}_{\mathrm{t}}\right)=\ln \mathrm{q}_{\mathrm{e}}-\mathrm{k}_{1} \mathrm{t} \\
& \mathrm{t} / \mathrm{qt}=1 / \mathrm{k} 2 \mathrm{qe} 2+1(\mathrm{t}) / \mathrm{qe} \\
& \mathrm{qt}=1 / \beta \ln (\alpha \beta)+1 / \beta \operatorname{lnt} \\
& \ln [-\ln (1-\alpha)]=n_{A V} K_{A V}+n_{A V} \ln t \\
& \log q_{t}=\log K+v \log t
\end{aligned}
$$


$\mathrm{q}_{\mathrm{t}}=\mathrm{K}_{\text {diff }} \mathrm{t}^{1 / 2}+\mathrm{C}$

Where $\mathrm{q}_{\mathrm{e}}$ and $\mathrm{q}_{\mathrm{t}}$ are quantity adsorbed at equilibrium and quantity absorbed at time $t$ in $\mathrm{mg} / \mathrm{g} . \mathrm{k}_{1}, \mathrm{~K}_{2}$ and $\mathrm{K}_{\text {diff }}$ are the rate constant for the pseudo-first-order in $\mathrm{min}^{-1}$, the pseudo-second-order kinetic in $\mathrm{g} / \mathrm{mg}$ $\mathrm{min}^{-1}$ and intraparticle diffusion in $\mathrm{mgg}^{-1} \mathrm{~min}^{-1 / 2} . \alpha$ is a constant related to chemisorption rate and $\beta$ is a constant which depicts the extent of surface coverage. The two constants ( $\alpha$ and $\beta$ ) can be calculated from the intercept and slope of the plot of $\mathrm{q}_{\mathrm{t}}$ versus lnt respectively. Avrami constants $\mathrm{n}_{\mathrm{AV}}$ and $\mathrm{K}_{\mathrm{AV}}$ relates to change in mechanism of adsorption. $\mathrm{C}$ represents thickness of the boundary layer.

\subsection{Adsorption kinetics validation}

Kinetics models were validated using the Chi square and sum square of error. These are expressed by equations (14) and (15).

$X^{2}=\sum_{i=1}^{n} \frac{\left(q_{\text {exp }}-q_{c a l}\right) 2}{q_{c a l}}$

$\mathrm{SSE}=\sum_{i=1}^{n}\left(q_{\text {cal }} q_{\text {exp }}\right)^{2}$

\subsection{Adsorption thermodynamic studies}

Thermodynamics parameters such as $\Delta \mathrm{G}^{\circ}, \Delta \mathrm{H}^{\mathrm{o}}$ and $\Delta \mathrm{S}^{\circ}$ gives insight into the spontaneity, feasibility and the nature of adsorbate-adsorbent. These parameters are obtained via calculations using equations (16) and (17).

$\ln K_{o}=\frac{\Delta \mathrm{S}^{\circ}}{R}-\frac{\Delta \mathrm{H}^{\circ}}{R T}$

$\Delta \mathrm{G}^{\mathrm{o}}=-\mathrm{RT} \ln \mathrm{K}_{\mathrm{o}}$

where $\mathrm{T}$ is the temperature in Kelvin, $\mathrm{R}$ is the gas constant; and $\mathrm{K}_{\mathrm{o}}$ can be obtained from $\mathrm{q}_{\mathrm{e}} / \mathrm{C}_{\mathrm{e}} \cdot \Delta \mathrm{H}^{\mathrm{o}}$ and $\Delta \mathrm{S}^{\circ}$ can be obtained from the plot of $\ln K_{\mathrm{o}}$ versus $1 / \mathrm{T}$.

\subsection{Results and discussion}

\subsection{Operational parameters effects on $\mathrm{Cu}^{2+}$ adsorption onto RHE and} ARHE

\subsection{1. $p H$ effects}

RHE and ARHE surface were highly protonated at low $\mathrm{pH}$. As $\mathrm{pH}$ increased, more hydroxonium ions are replaced with hydroxyl ions hence adsorbent surface becomes negatively charged and $\mathrm{Cu}^{2+}$ removal increased. Percentage removal reached optimum at $\mathrm{pH}$ of 5 for RHE and $\mathrm{pH}$ of 5.5 for ARHE. Optimum removal of $75.08 \%$ and $95.62 \%$ was obtained for RHE and ARHE respectively (Fig. 1). The percentage removal trend could be as a result of one or all of the following; (1) possibility of complex formation between the chloride ions of $\mathrm{HCl}$ used in obtaining the desired low $\mathrm{pH}$ and (2) competition between $\mathrm{H}^{+}$and $\mathrm{Cu}^{2+}$ for the available adsorption sites [Xie et al., 2017]. However, increased hydroxyl ion as $\mathrm{pH}$ increased and disappearance of $\mathrm{H}^{+}$made more adsorption sites available to $\mathrm{Cu}^{2+}$ hence percentage removal increased with increased $\mathrm{pH}$ reaching maximum at $\mathrm{pH}$ of 5 and 5.5. Further increase in $\mathrm{pH}$ can result into metal hydroxide and hydrated oxide formation hence limited metal ion will be available for uptake, this consequently will results in decrease in $\mathrm{Cu}^{2+}$ removal [Teow et al., 2018]. Some previous reports had optimum adsorption of $\mathrm{Cu}^{2+}$ at $\mathrm{pH} 5$ and 5.5 [Demiral and Güngor, 2016; De Castro et al., 2018].

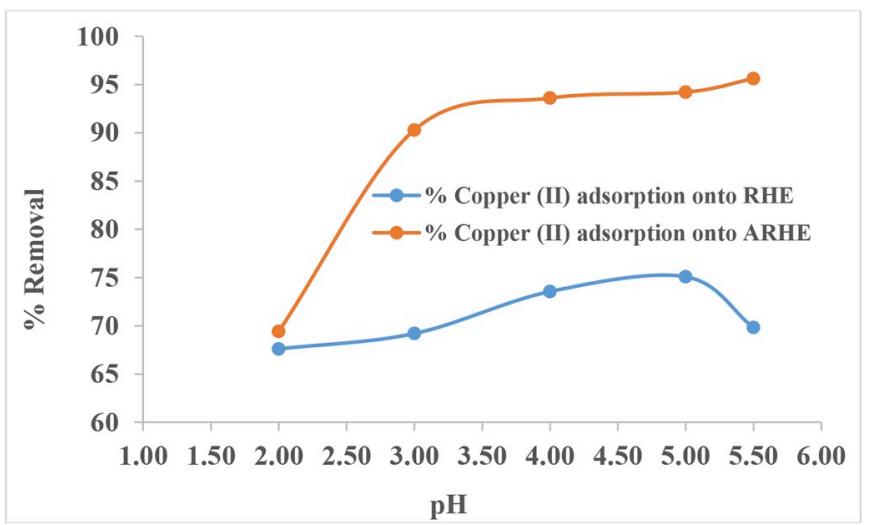

Fig. 1. Effects of adsorbate solution $\mathrm{pH}$ on $\mathrm{Cu}^{2+}$ removal onto RHE and ARHE. Conditions: Adsorbent dose $(1 \mathrm{~g} / \mathrm{L})$, Adsorbate concentration $(60 \mathrm{mg} / \mathrm{L})$, agitation time $(120 \mathrm{~min})$, Temperature $\left(26^{\circ} \mathrm{C}\right)$, agitation speed $(200 \mathrm{rpm})$.

\subsubsection{Adsorbent load effects}

Increase in adsorbent load results in increased adsorption sites hence increased percentage removal of $\mathrm{Cu}^{2+}$. Percentage $\mathrm{Cu}^{2+}$ adsorbed increased as adsorbents load rose from $1 \mathrm{~g} / \mathrm{L}$ to $4 \mathrm{~g} / \mathrm{L}$ with ARHE recording above $95 \%$ removal at $4 \mathrm{~g} / \mathrm{L}$ adsorbent load (Fig. 2 a \& b). Further increase beyond $4 \mathrm{~g} / \mathrm{L}$ in both systems resulted aggregation/agglomeration or overlap of adsorbent hence no further increase in $\mathrm{Cu}^{2+}$ percentage removal [Hajeeth et al., 2013]. Adsorbed quantity however decreased for both $\mathrm{RHE}-\mathrm{Cu}^{2+}$ and ARHE- $\mathrm{Cu}^{2+}$ systems. The decrease in available surface area which in turn results into decrease in adsorption capacity per unit mass of adsorbent may have been responsible for decrease in quantity adsorbed as adsorbent loading increased.

\subsubsection{Agitation speed effects}

Speed facilitates continuous contact rates hence influences adsorbent removal efficiency. Percentage removal of $\mathrm{Cu}^{2+}$ was observed to be almost constant across the agitation speed considered, a negligible increase in percentage adsorption was only observed for $300 \mathrm{rpm}$. Boundary layer effects of the $\mathrm{Cu}^{2+}$-RHE system may be low thus quick diffusion of $\mathrm{Cu}^{2+}$ onto the surface and into the pores of the adsorbent occurred hence agitation speed did not affect the percentage removal of $\mathrm{Cu}^{2+}$ in the $\mathrm{Cu}^{2+}$-RHE system [Djilani et al., 2015]. Percentage $\mathrm{Cu}^{2+}$ removal however was observed to gradually increased as the shaking speed increased from 150 to $300 \mathrm{rpm}$ (Fig. 3). Increased collision rate as a result of increased agitation enhanced $\mathrm{Cu}^{2+}$ transfer to the adsorption site hence high percentage adsorption is expected at high agitation speed.

\subsubsection{Ionic strength effects}

$\mathrm{Cu}^{2+}$ found in wastewater of many industrial wastewater comes with various other component and ions. Industries such as electroplating, copper polishing, printed circuit board, mining, metal cleaning, smelting, fertilizer producing, battery producing and paints manufacturing releases $\mathrm{Cu}^{2+}$ containing wastewater [Teow et al., 2018]. The effects of competing ions is important in order to predict $\mathrm{RH}$ and $\mathrm{ARH}$ applications in real industrial effluent treatments. Competition for adsorption site between $\mathrm{Na}^{+}$and $\mathrm{Cu}^{2+}$ was observed in both systems hence a reduction in $\mathrm{Cu}^{2+}$ percentage removal. Inverse relation was observed between $\mathrm{Cu}^{2+}$ percentage removal runs and $\mathrm{NaCl}$ concentration (Fig. 4). This suggest that at high electrolyte concentration greater competition occurred as huge amount of $\mathrm{Na}^{+}$exist in solution.

\subsubsection{Isothermal modeling and equilibrium adsorption data}

Quantity of $\mathrm{Cu}^{2+}$ adsorbed was observed to increase as the initial concentration increased (Fig. 5). High concentration generates high driving force strong enough to overcome the mass transfer barrier between the solid adsorbent and the aqueous $\mathrm{Cu}^{2+}$ solution. Percentage removal however played a reverse order hence the lowest concentration 

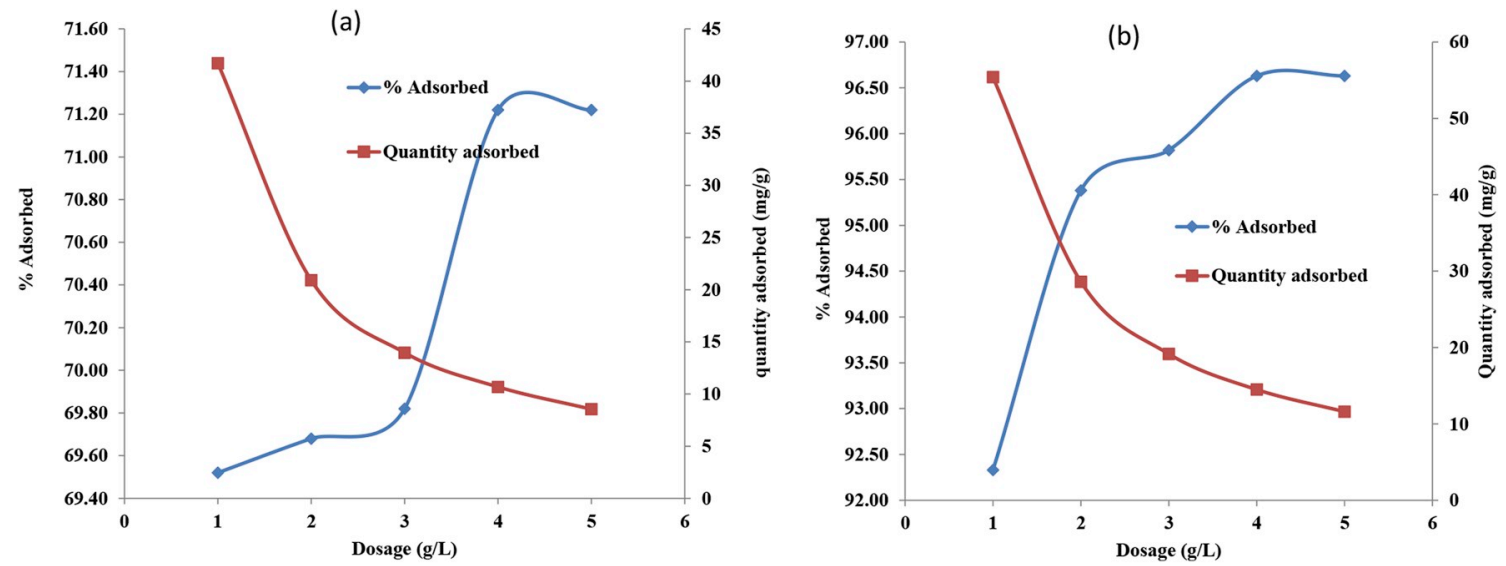

Fig. 2. Adsorbent load effects on $\mathrm{Cu}^{2+}$ adsorption onto RHE (a) and ARHE (b) Conditions: Concentration $60 \mathrm{mg} / \mathrm{L}$, agitation time ( $\left.120 \mathrm{~min}\right)$, Temperature (26 ${ }^{\circ} \mathrm{C}$ ), agitation speed (200 rpm), pH 5 and 5.5 .

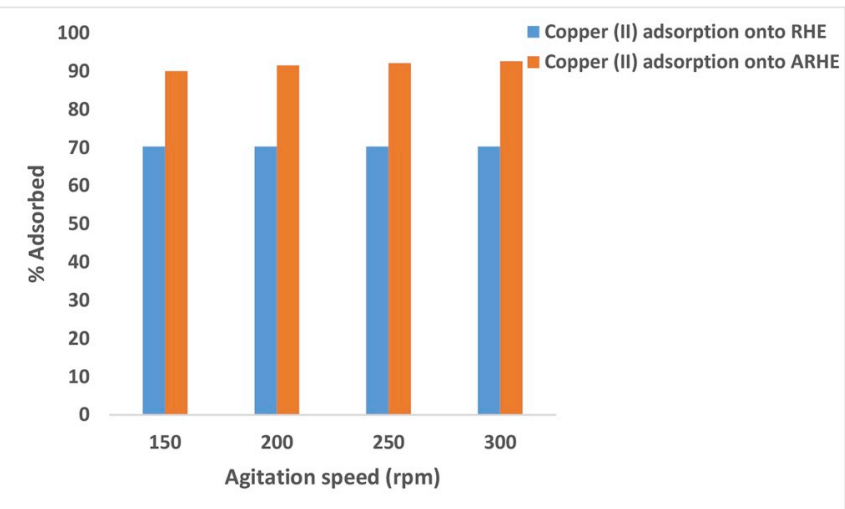

Fig. 3. Agitation speed effects on the uptake of $\mathrm{Cu}^{2+}$ onto RHE and ARHE. Conditions: Dosage $(1 \mathrm{~g} / \mathrm{L})$, concentration $60 \mathrm{mg} / \mathrm{L}$, Temperature $\left(26^{\circ} \mathrm{C}\right)$, agitation time (120 $\mathrm{min}), \mathrm{pH} 5$ and 5.5 .

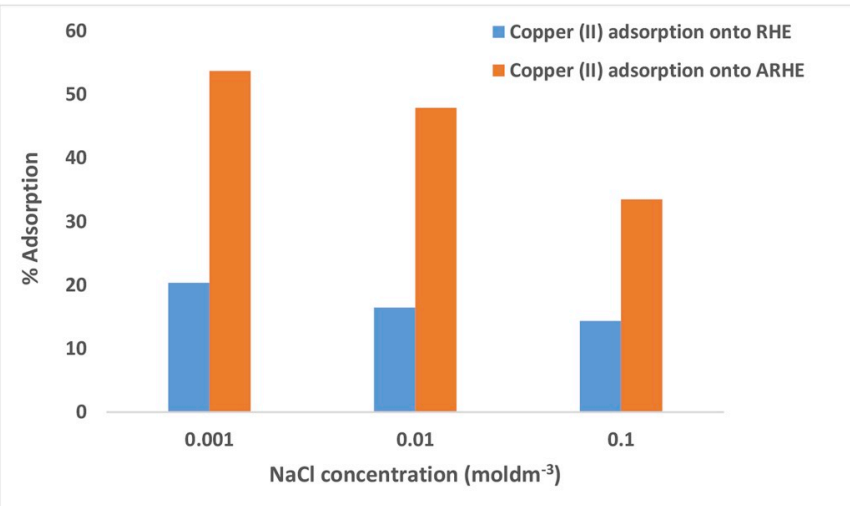

Fig. 4. Effects of ionic strength on the uptake of $\mathrm{Cu}^{2+}$ onto RHE and ARHE. Conditions: Dosage $(1 \mathrm{~g} / \mathrm{L})$, concentration $60 \mathrm{mg} / \mathrm{L}$, agitation speed $(200 \mathrm{rpm})$, Temperature $\left(26^{\circ} \mathrm{C}\right)$, agitation time $(120 \mathrm{~min}), \mathrm{pH} 5$ and 5.5 .

(20 $\mathrm{mg} / \mathrm{L}$ ) had the highest percentage removal of $63.80 \%$ and $99.25 \%$ for RHE and ARHE respectively.

3.1.5.1. Isothermal. Isothermal parameters for the uptake of $\mathrm{Cu}^{2+}$ onto RHE and ARHE are listed in Table 1. Comparing the correlation coefficient, the Freundlich adsorption isotherm best described their adsorption data than other adsorption isotherms used $\left(\mathrm{R}^{2}=0.9608\right.$ and 0.9301 for RHE and ARHE respectively). This suggests a heterogeneous adsorption of $\mathrm{Cu}^{2+}$ onto non uniform surfaces. The dimensionless

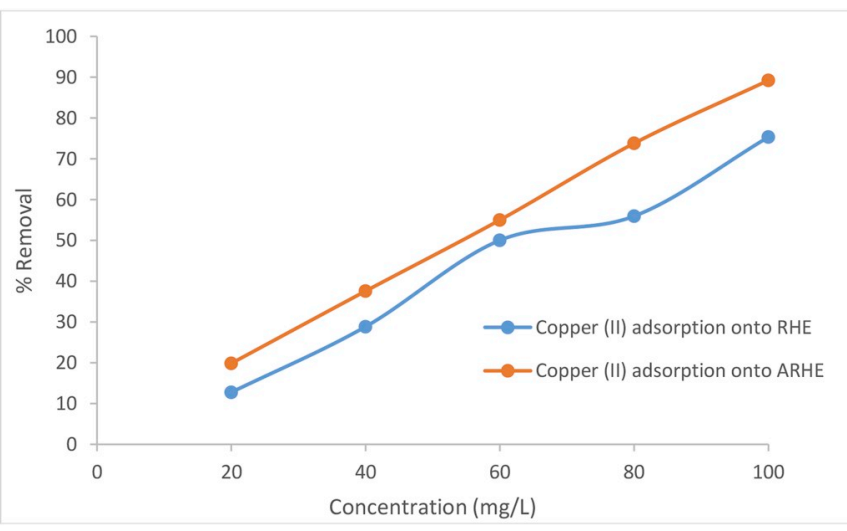

Fig. 5. Effects of concentration on the uptake of $\mathrm{Cu}^{2+}$ onto RHE and ARHE. Conditions: Dosage $(1 \mathrm{~g} / \mathrm{L})$, agitation speed $(200 \mathrm{rpm})$, agitation time (120 min), Temperature $\left(26^{\circ} \mathrm{C}\right)$, $\mathrm{pH} 5$ and 5.5 .

Table 1

Isothermal parameters for the uptake of $\mathrm{Cu}^{2+}$ onto RHE and ARHE.

\begin{tabular}{llll}
\hline Isotherms & constants & RHE & ARHE \\
\hline Langmuir & $\mathrm{q}_{\max }(\mathrm{mg} / \mathrm{g})$ & 81.97 & 103.09 \\
& $\mathrm{~K}_{\mathrm{L}}\left(\mathrm{L} \cdot \mathrm{mg}^{-1}\right)$ & 0.15 & 0.3731 \\
& $\mathrm{R}_{\mathrm{L}}$ & 0.06 & 0.0261 \\
& $\mathrm{R}^{2}$ & 0.7734 & 0.8607 \\
Freundlich & $\mathrm{K}_{\mathrm{F}}$ & 1.12 & 34.98 \\
& $\mathrm{n}$ & 0.78 & 2.9239 \\
& $\mathrm{R}^{2}$ & 0.9608 & 0.9301 \\
Temkin & $\mathrm{A}$ & 0.24 & 16.36 \\
& $\mathrm{~B}$ & 37.93 & 14.674 \\
& $\mathrm{~b}$ & 65.77 & 169.97 \\
$\mathrm{D}-\mathrm{R}$ & $\mathrm{R}^{2}$ & 0.7344 & 0.7977 \\
& $\mathrm{q}_{\mathrm{o}}(\mathrm{mg} / \mathrm{g})$ & 79.46 & 48.58 \\
& $\beta\left(\mathrm{mol}^{2} . \mathrm{KJ}^{-2}\right)$ & 0.02 & 0.00005 \\
& $\mathrm{E}\left(\mathrm{kJmol}^{-1}\right)$ & 5.54 & 100 \\
& $\mathrm{R}^{2}$ & 0.815 & 0.6741 \\
\hline
\end{tabular}

factor $\mathrm{R}_{\mathrm{L}}$ obtained from Langmuir isotherm was less than 1 for the two systems. The Langmuir maximum monolayer adsorption capacity $\left(\mathrm{q}_{\max }\right)$ was obtained for RHE- $\mathrm{Cu}^{2+}$ and ARHE- $\mathrm{Cu}^{2+}$ are $81.97 \mathrm{mg} / \mathrm{g}$ and $103.09 \mathrm{mg} / \mathrm{g}$ respectively (Table 1 ) suggesting that acid treatment enhanced adsorption capacity. The Branauer-Emmett-Teller (BET) surface area obtained for RHE was $0.0357 \mathrm{~m}^{2} / \mathrm{g}$ while ARHE gave $1.8600 \mathrm{~m}^{2} / \mathrm{g}$ hence the better adsorption capacity showed by ARHE. The energy of adsorption revealed uptake of $\mathrm{Cu}^{2+}$ onto RHE was physical in nature while ARHE chemisorbed $\mathrm{Cu}^{2+}$. The great decrease in the intensity of various functional groups absorption bands in ARHE- 
Table 2

Comparison of maximum monolayer adsorption capacities obtained with others reported in literature.

\begin{tabular}{lll}
\hline Adsorbents & $\mathrm{q}_{\max }(\mathrm{mg} / \mathrm{g})$ & References \\
\hline Functionalized cotton & 95.24 & Niu et al. (2017) \\
Cellulose hydrogel & 52.30 & Teow et al. (2018) \\
Coated bentonite & 46.95 & Mohammed and Samaka (2018) \\
Modified bentonite & 27.00 & De Castro et al. (2018) \\
Treated fish waste & 2.10 & El Haoutia et al. (2019) \\
Acid treated dika nut & 103.09 & Inyinbor et al. (2019) \\
Raw Raphia hookeri & 81.97 & This study \\
Treated Raphia hookeri & 103.10 & This study \\
\end{tabular}

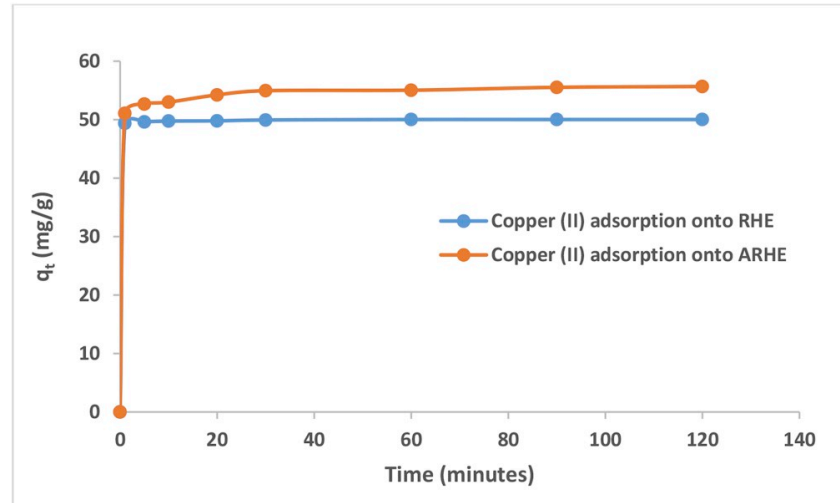

Fig. 6. Contact time effects on the uptake of $\mathrm{Cu}^{2+}$ onto RHE and ARHE. Conditions: Agitation speed (200 rpm), dosage ( $1 \mathrm{~g} / \mathrm{L})$, Concentration (60 mg/ L), Temperature $\left(26^{\circ} \mathrm{C}\right), \mathrm{pH} 5$ and 5.5 .

$\mathrm{Cu}^{2+}$ (Supplementary 2) reveals the use of such functional groups in $\mathrm{Cu}^{2+}$ removal. Table 2 compares the $\mathrm{q}_{\max }$ for $\mathrm{Cu}^{2+}$ - $\mathrm{RHE}$ and $\mathrm{Cu}^{2+}$. ARHE systems with some previous work and shows better efficiency.

\subsubsection{Contact time effects and kinetics modeling}

Rapid initial uptake of $\mathrm{Cu}^{2+}$ was observed for the two adsorbents studied. Numerous available adsorption site on fresh adsorbents may have been responsible for this. Subsequently, $\mathrm{Cu}^{2+}$ removal was slow and then goes to equilibrium. The eventual slow adsorption of $\mathrm{Cu}^{2+}$ is as result of pores diffusion. Quantity obtained at equilibrium were 50.03 and $55.67 \mathrm{mg} / \mathrm{g}$ for RHE and ARHE respectively (see Fig. 6).

3.1.6.1. Kinetics modeling. Adsorption kinetic data fitted best into pseudo second order kinetic, close agreement was recorded between the experimentally determined quantity adsorbed at equilibrium and the corresponding calculated values. Hence, sum square of error (SSE) and chi square $\left(X^{2}\right)$ and SSE were very low. This further ascertain that chemisorption was the predominant mechanism of $\mathrm{Cu}^{2+}$ adsorption. This agrees with previous reports (Lalhmunsiama et al., 2013). A validation of the multi adsorption mechanism was observed by the plot of $\mathrm{q}_{\mathrm{t}}$ against the square root of time (Figure not shown) which did not pass through the origin hence boundary layer diffusion also occurred in the uptake of $\mathrm{Cu}^{2+}$ onto RHE and ARHE. While a single layer adsorption profile was obtained for the $\mathrm{Cu}^{2+}$-RHE system, multilayer profile was obtained for the intraparticle diffusion model plot of $\mathrm{Cu}^{2+}$-ARHE system. This suggests that adsorption $\mathrm{Cu}^{2+}$ onto ARHE occurred in two stages, the first steeper part depicts the diffusion of $\mathrm{Cu}^{2+}$ towards the adsorbent surface while the second part is the gradual stage where adsorbates penetrate into the pores of the adsorbent thus intraparticle diffusion was the rate limiting step (Inyinbor et al., 2016 a). Boundary effect was higher for the gradual stage hence lower diffusion rate (Table 3). Driving force at this stage has greatly reduced since concentration must have reduced. Although
Table 3

Comparison of kinetics model parameters for the adsorption of $\mathrm{Cu}^{2+}$ onto RHE and ARHE.

\begin{tabular}{|c|c|c|}
\hline \multirow[t]{2}{*}{ Constants } & Adsorbents & ARHE \\
\hline & \multicolumn{2}{|l|}{ RHE } \\
\hline $\begin{array}{l}\mathrm{q}_{\mathrm{e}} \text { experimental }(\mathrm{mg} / \mathrm{g}) \\
\text { Pseudo first order }\end{array}$ & 50.03 & 55.67 \\
\hline $\mathrm{q}_{\mathrm{e}}$ calculated $(\mathrm{mg} / \mathrm{g})$ & 0.62 & 3.51 \\
\hline $\mathrm{K}_{1} \times 10^{-2}\left(\mathrm{~min}^{-1}\right)$ & 6.43 & 3.52 \\
\hline $\mathrm{R}^{2}$ & 0.9325 & 0.9317 \\
\hline SSE & 2441.35 & 2720.67 \\
\hline$X^{2}$ & 3937.66 & 775.118 \\
\hline \multicolumn{3}{|l|}{ Pseudo second order } \\
\hline $\mathrm{q}_{\mathrm{e} \text { calculated }}(\mathrm{mg} / \mathrm{g})$ & 50 & 55.87 \\
\hline $\mathrm{K}_{2} \times 10^{-1}\left(\mathrm{gmg}^{-1} \mathrm{~min}^{-1}\right)$ & 4 & 0.43 \\
\hline $\mathrm{R}^{2}$ & 1 & 1 \\
\hline SSE & 0.0009 & 0.04 \\
\hline$X^{2}$ & $1.8 \times 10^{-5}$ & 0.00072 \\
\hline \multicolumn{3}{|l|}{ Elovich } \\
\hline$\alpha_{\mathrm{El}}(\mathrm{mg} / \mathrm{g} \cdot \min )$ & $5.31 \times 10^{147}$ & $2.12 \times 10^{21}$ \\
\hline$\beta_{\mathrm{El}}(\mathrm{g} / \mathrm{mg})$ & 6.93 & 1.01 \\
\hline $\mathrm{R}^{2}$ & 0.9699 & 0.9751 \\
\hline \multicolumn{3}{|l|}{ Avrami } \\
\hline $\mathrm{n}_{\mathrm{Av}}$ & 0.1018 & 0.17 \\
\hline $\mathrm{K}_{\mathrm{av}}\left(\min ^{-1}\right)$ & 14.12 & 4.43 \\
\hline $\mathrm{R}^{2}$ & 0.8659 & 0.8909 \\
\hline \multicolumn{3}{|l|}{ Fractional power } \\
\hline $\mathrm{V}\left(\min ^{-1}\right)$ & 0.0029 & 0.02 \\
\hline $\mathrm{K}(\mathrm{mg} / \mathrm{g})$ & 49.39 & 51.11 \\
\hline $\mathrm{KV}(\mathrm{mg} / \mathrm{g} / \mathrm{min})$ & 0.14 & 0.95 \\
\hline $\mathrm{R}^{2}$ & 0.9697 & 0.9749 \\
\hline \multicolumn{3}{|l|}{ Intra particle diffusion } \\
\hline $\mathrm{C}_{1}\left(\mathrm{mgg}^{-1}\right)$ & 49.49 & 50.39 \\
\hline $\mathrm{K}_{1 \text { diff }}\left(\mathrm{mgg}^{-1} \mathrm{~min}^{-1 / 2}\right)$ & 0.0597 & 0.87 \\
\hline $\mathrm{R}_{1}^{2}$ & 0.8005 & 0.9661 \\
\hline $\mathrm{C}_{2}\left(\mathrm{mgg}^{-1}\right)$ & - & 54.11 \\
\hline $\mathrm{K}_{2 \text { diff }}\left(\mathrm{mgg}^{-1} \mathrm{~min}^{-1 / 2}\right)$ & - & 0.14 \\
\hline $\mathrm{R}_{2}^{2}$ & - & 0.8946 \\
\hline
\end{tabular}

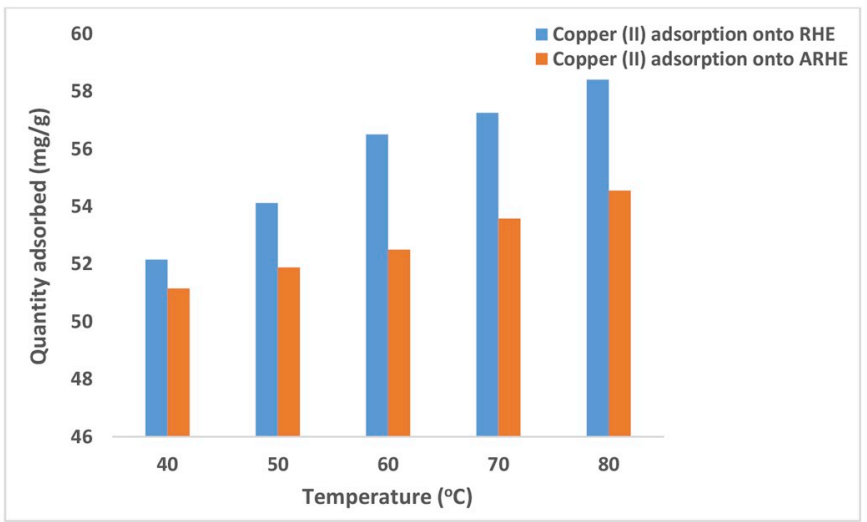

Fig. 7. Temperature effects on the uptake of $\mathrm{Cu}^{2+}$ onto RHE and ARHE. Conditions: Dosage $(1 \mathrm{~g} / \mathrm{L})$, Concentration $(60 \mathrm{mg} / \mathrm{L})$, Contact time $(120 \mathrm{~min})$, agitation speed (200 rpm), pH 5 and 5.5.

adsorption kinetic may be slow, however, the pore diffusion involved in $\mathrm{Cu}^{2+}$-ARHE system suggests that ARHE will be efficient and may find applications in real industrial effluents treatments.

\subsubsection{Temperature effects and thermodynamic studies}

Removal efficiency of RHE and ARHE increased with temperature. Removal efficiency was higher in RHE than ARHE and it varied between $52.15 \mathrm{mg} / \mathrm{g}$ and $58.40 \mathrm{mg} / \mathrm{g}$ as temperature increased from 303 to $353 \mathrm{~K}$. At maximum temperature studied $(353 \mathrm{~K})$, quantity of $\mathrm{Cu}^{2+}$ adsorbed onto ARHE was $54.55 \mathrm{mg} / \mathrm{g}$. Increase in the quantity of $\mathrm{Cu}^{2+}$ adsorbed as the temperature increased may be attributed to increase in 
Table 4

Thermodynamics parameters for adsorption of $\mathrm{Cu}^{2+}$ onto RHE and ARHE.

\begin{tabular}{|c|c|c|c|c|c|c|c|}
\hline Adsorbents & $\Delta \mathrm{H}^{\mathrm{o}}(\mathrm{kJ} / \mathrm{mol})$ & $\Delta \mathrm{S}^{\circ}(\mathrm{J} / \mathrm{mol} / \mathrm{K})$ & $\Delta \mathrm{G}^{\mathrm{o}}(\mathrm{kJ} / \mathrm{mol})$ & & & & \\
\hline & & & 313 & 323 & 333 & 343 & 353 \\
\hline RHE & 38.72 & 138.97 & -4.93 & -5.96 & -7.7 & -8.65 & -10.56 \\
\hline ARHE & 12.47 & 54.09 & -4.57 & -4.98 & -5.39 & -6.05 & -6.76 \\
\hline
\end{tabular}

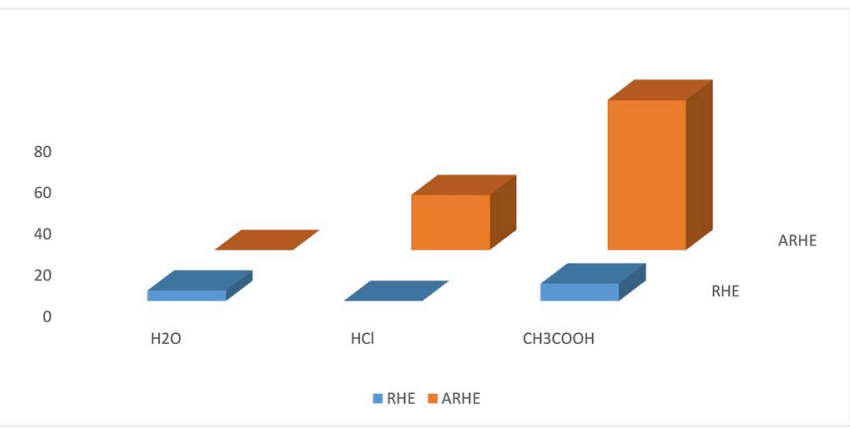

Fig. 8. Percentage $\mathrm{Cu}^{2+}$ desorption from RHE and ARHE with different eluent.

kinetic energy of copper ions vis-à-vis activation of the adsorbent adsorption site (Rafiq et al., 2014) (see Fig. 7).

3.1.7.1. Thermodynamic studies. Positive values obtained for $\Delta \mathrm{H}^{\circ}$ (Table 4) suggests that adsorption process was endothermic. Solidliquid interphase disorderliness rate was found greater in $\mathrm{Cu}^{2+}$-RHE system. Negativity of $\Delta \mathrm{G}^{\mathrm{o}}$ increased with increasing temperature hence high temperature favoured the two adsorption systems. $\Delta \mathrm{G}^{\circ}$ negative values suggests that adsorption process was spontaneous and visible. High negative values also indicates that prepared adsorbent would be highly effective for pollutant uptake in high temperature media thus suitable for hot wastewater treatment.

\subsection{Desorption studies of $\mathrm{Cu}^{2+}-\mathrm{RHE}$ and $\mathrm{Cu}^{2+}$-ARHE system}

Percentage $\mathrm{Cu}^{2+}$ desorption from RHE surface were low, 4.95\%, $0.03 \%$, and $8.30 \%$ for neutral water, $0.1 \mathrm{M} \mathrm{HCl}$ and $0.1 \mathrm{M} \mathrm{CH}_{3} \mathrm{COOH}$ respectively (Fig. 8). Some level of chemisorption may have taken place in the $\mathrm{Cu}^{2+}$-RHE system. However, $\mathrm{CH}_{3} \mathrm{COOH}$ efficiently desorbed $\mathrm{Cu}^{2+}$ from ARHE surface with $72.65 \%$ desorption efficiency while desorption efficiency obtained for $\mathrm{HCl}$ was $25.62 \%$. High desorption efficiency obtained with $\mathrm{CH}_{3} \mathrm{COOH}$ further shows that chemisorption was predominant in the $\mathrm{Cu}^{2+}$-ARHE system (Bello et al., 2008; Inyinbor et al., 2017). Low desorption efficiency of neutral water has previously been reported for chemisorbed heavy metals (Li et al., 2019).

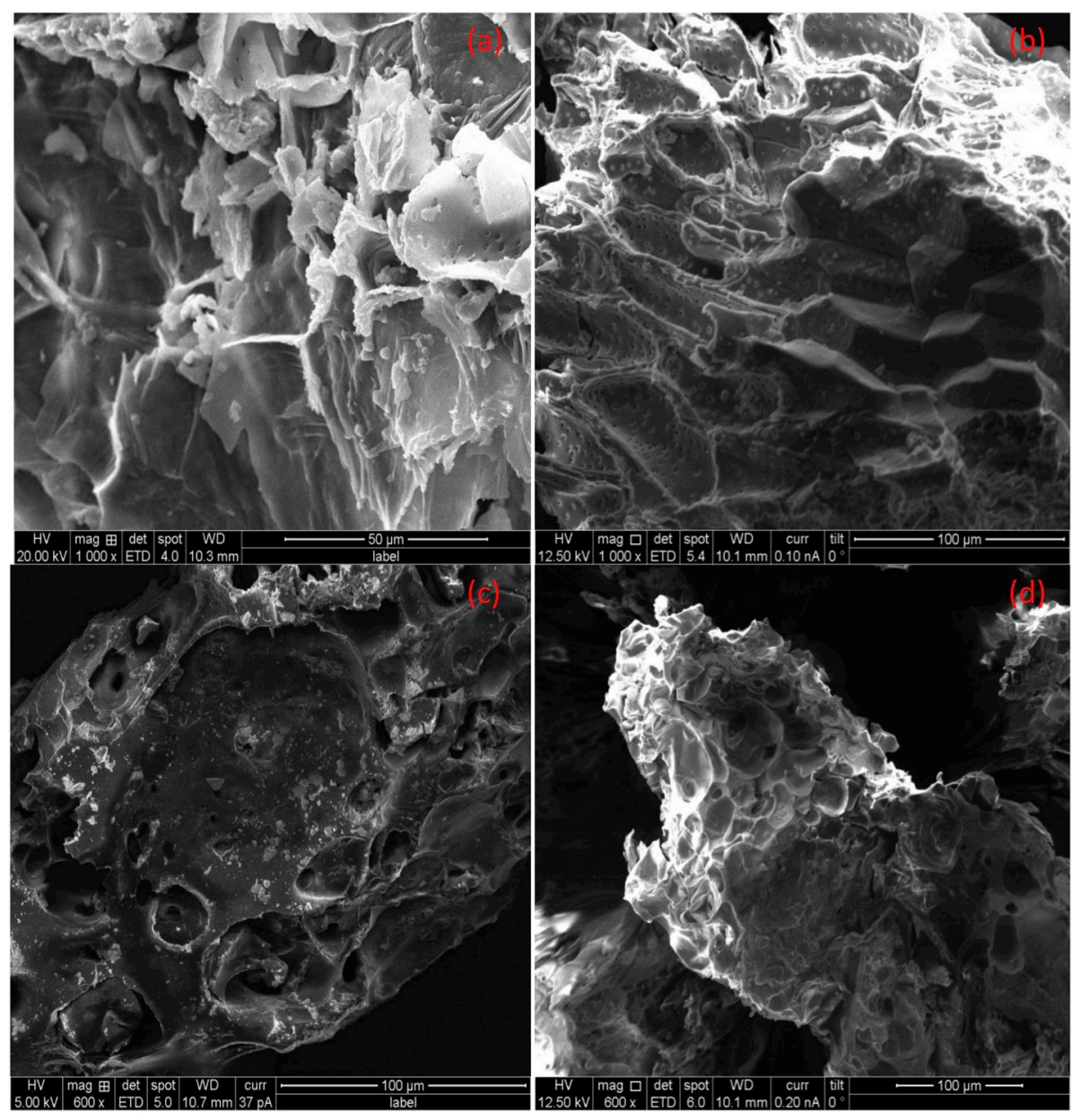

Fig. 9. SEM image of RHE before $\mathrm{Cu}^{2+}$ adsorption (a) and after $\mathrm{Cu}^{2+}$ adsorption (b) and ARHE before $\mathrm{Cu}^{2+}$ adsorption (c) and after $\mathrm{Cu}^{2+}$ adsorption (d). 


\subsection{Comparison of pre and post adsorption characterization of RHE and ARHE}

The feather like feature of RHE before adsorption of $\mathrm{Cu}^{2+}$ has been replaced with a thick galloping surface after $\mathrm{Cu}^{2+}$ uptake. (Fig. 9a and b). Fig. $9 \mathrm{c}$ and $\mathrm{d}$ shows the SEM image of ARHE before and after $\mathrm{Cu}^{2+}$ adsorption, rough surface characterized ARHE after $\mathrm{Cu}^{2+}$ uptake as against the initial smooth surface. Treated agrowaste usually show increased porosity when compared with raw agrowaste. The lignocellulosic characteristics of agrowaste makes them suitable for pollutants uptake (Omo-Okoro et al., 2018). Similar trend in morphological structure change of pineapple biomass after dye uptake was previously reported (Mahamad et al., 2015).

\section{Conclusion}

RHE and ARHE were highly effective in the scavenging of $\mathrm{Cu}^{2+}$ with removal efficiency reaching $95.62 \%$ at optimum $\mathrm{pH}$ of 5.5 for ARHE. Agitation speed slightly increased adsorption of $\mathrm{Cu}^{2+}$ while temperature greatly enhanced adsorption efficiency of the two adsorbents. Hence the applications of RHE and ARHE in real industrial effluent will be effective since both adsorbents are stable at high temperature. Freundlich adsorption isotherm best described both $\mathrm{Cu}^{2+}$. RHE and $\mathrm{Cu}^{2+}$-ARHE systems while the adsorption kinetics data best fitted into the pseudo second order kinetic model.

\section{Appendix A. Supplementary data}

Supplementary data to this article can be found online at https:// doi.org/10.1016/j.scp.2019.100141.

\section{References}

Adekola, F.A., Ayodele, S.B., Inyinbor, A.A., 2019. Activated biochar prepared from plantain peels: characterization and Rhodamine B adsorption data set. Chem. Data Collect. 19, 100170.

Aharoni, C., Ungarish, M., 1976. Kinetics of activated chemisorptions. Part I: the nonElovichian part of the isotherm. J. Chem. Soc. Faraday. Trans. 72, 265-268.

Avrami, M., 1940. Kinetics of phase change: transformation-time relations for random distribution of nuclei. J. Chem. Phys. 8, 212-224.

Bello, O.S., Adeogun, I.A., Ajaelu, J.C., Fehintola, E.O., 2008. Adsorption of methylene blue onto activatedcarbon derived from periwinkle shells: kinetics and equilibrium studies. Chem. Ecol. 24, 285-295.

De Castro, M.L.F.A., Abad, M.L.B., Sumalinog, D.A.G., Abarca, R.R.M., Paoprasert, P., de Luna, M.D.G., 2018. Adsorption of Methylene Blue dye and Cu(II) ions on EDTA modified bentonite: isotherm, kinetic and thermodynamic studies. Sustain. Environ. Res 28, 197-205.

Demiral, H., Güngor, C., 2016. Adsorption of copper(II) from aqueous solutions on activated carbon prepared from grape bagasse. J. Clean. Prod. 124, 103-113.

Djilani, C., Zaghdoudi, R., Djazi, F., Bouchekima, B., Lallam, A., Modarressi, A., Rogalski, M., 2015. Adsorption of dyes on activated carbon prepared from apricot stones andcommercial activated carbon. J. Taiwan Inst. Chem. Eng. 53, 112-121.

Dubinin, M.M., Radushkevich, L.V., 1947. Equation of the characteristic curve of activated Charcoal. In: Proceedings of Academy of Science Physics Chemistry USSR. 55. pp. 331-333.

El Haoutia, R., Anfara, Z., Chennaha, A., Amaterza, E., Zbairb, M., El Alema, N. Benlhachemia, A., Ezahria, M., 2019. Synthesis of sustainable mesoporous treated fish waste as adsorbent for copper removal. Groundwater Sustain. Develop. 8, 1-9.

Freundlich, H.M.F., 1906. Over the adsorption in solution. Z. Phys. Chem. 57, 385-470.

Genthe, B., Kapwata, T., Roux, W.L., Chamier, J., Wright, C.Y., 2018. The reach of human health risks associated with metals/me talloids in water and vegetables along a contaminated river catchment: South Africa and Mozambique. Chemosphere 199, 1-9.

Hajeeth, T., Vijayalakshmi, K., Gomathi, T., Sudha, P.N., 2013. Removal of Cu(II) and Ni (II) using cellulose extracted from sisal fiber and cellulose-g-acrylic acid copolymer. Int. J. Biol. Macromol. 62, 59-65.

Harvey, P.J., Handley, H.K., Taylor, M.P., 2016. Widespread copper and lead contamination of household drinking water, New South Wales, Australia. Environ. Res. $151,275-285$.
Ho, Y.S., McKay, G., 1999. Pseudo-second order model for sorption processes. Process Biochem. 34, 451-465.

Inyinbor, A.A., Adekola, F.A., Olatunji, G.A., 2015. Adsorption of Rhodamine B dye from aqueous solution on Irvingia gabonensis biomass: kinetics and thermodynamics studies. South Afr. J. Chem. 68, 115-125.

Inyinbor, A.A., Adekola, F.A., Olatunji, G.A., 2016. Kinetic and thermodynamic modeling of liquid phase adsorption of Rhodamine B dye onto Raphia hookerie fruit epicarp. Water Resour. Industr. 15, 14-27.

Inyinbor, A.A., Adekola, F.A., Olatunji, G.A., 2016a. Liquid phase adsorption of Rhodamine B onto acid treated Raphia hookerie epicarp: kinetics, Isotherm and thermodynamics studies. S. Afr. J. Chem. 69, 218-226.

Inyinbor, A.A., Adekola, F.A., Olatunji, G.A., 2017. Liquid phase adsorptions of Rhodamine B dye onto raw and chitosan supported mesoporous adsorbents: isotherms and kinetics studies. Appl. Water Sci. 7, 2297-2307.

Inyinbor, A.A., Adekola, F.A., Dada, A.O., Oluyori, A.P., Olatunji, G.A., Fanawopo, O.F., Oreofe, T.A., Abodunrin, T.O., 2019. Novel acid treated biomass: applications in $\mathrm{Cu}^{2+}$ scavenging, Rhodamine $\mathrm{B} / \mathrm{Cu}^{2+}$ binary solution and real textile effluent treatment. Environ. Technol. Innovat. 13, 37-47.

Lagergren, S., Svenska, B.K., 1898. On the theory of so-called adsorption of materials, R. Swedish Academy Science Doc. Bandwagon 24, 1-13.

Lalhmunsiama, Lee, S.M., Tiwari, D., 2013. Manganese oxide immobilized activated carbons in the remediation ofaqueous wastes contaminated with copper(II) and lead (II). Chem. Eng. J. 225, 128-137.

Langmuir, I., 1916. The constitutional and fundamental properties of solids and liquids. J. Am. Chem. Soc. 38, 2221-2295.

Li, X., Liu, Y., Zhang, C., Wen, T., Zhuang, L., Wang, X., Song, G., Chen, D., Ai, Y., Hayat, T., Wang, X., 2018. Porous $\mathrm{Fe}_{2} \mathrm{O}_{3}$ microcubes derived from metal organic frameworks for efficient elimination of organic pollutants and heavy metal ions. Chem. Eng. J. $336,241-252$.

Li, L.Y., Gong, X.D., Abida, O., 2019. Waste-to-resources: exploratory surface modification of sludge-based activated carbon by nitric acid for heavy metal adsorption. Waste Manag. 87, 375-386.

Liu, F., Zhou, K., Chen, Q., Wang, A., Chen, W., 2019. Application of magnetic ferrite nanoparticles for removal of $\mathrm{Cu}$ (II) from copper-ammonia wastewater. J. Alloy. Comp. 773, 140-149.

Mahamad, M.N., Zaini, M.A.A., Zakaria, Z.A., 2015. Preparation and characterization of activated carbon from pineapple waste biomass for dye removal. Int. Biodeterior. Biodegrad. 102, 274-280.

Meng, Q., Peng, B., Shen, C., 2018. Synthesis of F127/PAA hydrogels for removal of heavy metal ions from organic wastewater. Colloids Surfaces B Biointerfaces 167, $176-182$.

Mohammed, A.A., Samaka, I.S., 2018. Bentonite coated with magnetite Fe3O4 nanoparticles as a novel adsorbent for copper (II) ions removal from water/wastewater. Environ. Technol. Innovat. 10, 162-174.

Niu, Y., Li, K., Ying, D., Wang, Y., Jia, J., 2017. Novel recyclable adsorbent for the removal of copper (II) and lead (II) from aqueous solution. Bioresour. Technol. 229, 63-68.

Nthunya, L.N., Masheane, M.L., Malinga, S.P., Nxumalo, E.N., Mamba, B.B., Mhlanga, S.D., 2017. Determination of toxic metals in drinking water sources in the chief albert luthuli local municipality in mpumalanga, South Africa. Phys. Chem. Earth 100, 94-100.

Omo-Okoro, P.N., Daso, A.P., Okonkwo, J.O., 2018. A review of the application of agricultural wastes as precursor materials for the adsorption of per-and polyfluoroalkyl substances: a focus on current approaches and methodologies. Environ. Technol. Innovat. 9, 100-114.

Rafiq, Z., Nazir, R., Shahwar, D., Shah, M.R., Ali, S., 2014. Utilization of magnesium and zinc oxide nano-adsorbents as potential materials for treatment of copper electroplating industry wastewater. J. Environ. Chem. Eng. 2, 642-651.

Siyal, A.A., Shamsuddin, M.R., Khan, M.I., Rabat, N.E., Zulfiqar, M., Man, Z., Siame, J., Azizli, K.A., 2018. A review on geopolymers as emerging materials for the adsorption of heavy metals and dyes. J. Environ. Manag. 224, 327-339.

Teow, Y.H., Kam, L.M., Mohammad, A.W., 2018. Synthesis of cellulose hydrogel for copper (II) ions adsorption. J. Environ. Chem. Eng. 6, 4588-4597.

Temkin, M.I., Pyzhev, V., 1940. Kinetics of ammonia synthesis on promoted iron catalyst. Acta Physiochimica USSR 12, 327-356.

Titilawo, Y., Adeniji, A., Adeniyi, M., Okoh, A., 2018. Determination of levels of some metal contaminants in the freshwater environments of Osun State, Southwest Nigeria: a risk assessment approach to predict health threat. Chemosphere 211, 834-843.

Weber, W.J., Morris, J.C., 1963. Kinetics of adsorption on carbon from solution. J. Sanity Eng. Div. Am. Soc. Civil Eng. 89, 31-59.

WHO, 2003. Copper in Drinking-Water. Background Document for Preparation of WHO Guidelines for Drinking-Water Quality. World Health Organization, Geneva (WHO/ SDE/WSH/03.04/88).

Xiao, J., Wang, L., Deng, L., Jin, Z., 2019. Characteristics, sources, water quality and health risk assessment of trace elements in river water and well water in the Chinese Loess Plateau. Sci. Total Environ. 650, 2004-2012.

Xie, X., Deng, R., Pang, Y., Bai, Y., Zheng, W., Zhou, Y., 2017. Adsorption of copper(II) by sulfur microparticles. Chem. Eng. J. 314, 434-442. 